\title{
THE PRODUCTIVITY ADVANTAGE AND GLOBAL SCOPE OF U.S. MULTINATIONAL FIRMS
}

\author{
by \\ Raymond Mataloni, Jr. * \\ U.S. Bureau of Economic Analysis
}

CES 11-23

August, 2011

The research program of the Center for Economic Studies (CES) produces a wide range of economic analyses to improve the statistical programs of the U.S. Census Bureau. Many of these analyses take the form of CES research papers. The papers have not undergone the review accorded Census Bureau publications and no endorsement should be inferred. Any opinions and conclusions expressed herein are those of the author(s) and do not necessarily represent the views of the U.S. Census Bureau. All results have been reviewed to ensure that no confidential information is disclosed. Republication in whole or part must be cleared with the authors.

To obtain information about the series, see www.census.gov/ces or contact Cheryl Grim, Editor, Discussion Papers, U.S. Census Bureau, Center for Economic Studies 2K130B, 4600 Silver Hill Road, Washington, DC 20233, CES.Papers.List@census.gov. 


\begin{abstract}
This paper examines whether the productivity of U.S. business establishments is related to the extent to which their parent firms are globally engaged--from being an exporter to being a fledgling multinational that has taken a few cautious forays into foreign markets to being a seasoned multinational with extensive foreign operations. Theory suggests that multinationals possess proprietary assets that confer a productivity advantage over their domestically-oriented rivals, and that this advantage is positively correlated with the global scope of a firm's operations. That is, those firms with the greatest productivity advantage are able to absorb the costs and overcome the risks of operating in a wide range of foreign countries, from those where it is relatively riskfree and economical to operate, to those where it is risky, difficult, and costly. This connection between the multinational's widening of its geographic scope of operations and its productivity can be self-reinforcing. Once a multinational has successfully operated in a risky environment, it may benefit from learning effects that can lower the cost and risk of further enlargement of geographic scope. The positive correlation between a firm's global engagement and its level of productivity has already been demonstrated. This paper extends that research by testing whether the correlation holds up when productivity is measured at the level of the individual establishment, rather than at the level of the consolidated business enterprise. It also examines whether the correlation between global engagement and productivity exists in nonmanufacturing industries. Finally, it examines whether linkages between the multinational's domestic and foreign operations, in the form of imports of goods by the parent company from its foreign affiliates, enhance the productivity of the multinational's domestic business establishments.
\end{abstract}

The findings confirm the positive correlation between global scope and productivity and demonstrate that it holds for both manufacturing and non-manufacturing industries. The effect of imports of goods from foreign affiliates on the productivity of the establishments of their parent firm depend on the geographic location of the affiliates: Imports from affiliates in high-income countries tend to be associated with high productivity whereas those from affiliates in low income countries tend to be associated with low productivity. The study was made possible by combining BEA enterprise-level data on the U.S. operations of U.S. multinational firms with data on all U.S. business establishments collected by the Census Bureau in the U.S. economic census covering 2002.

Keywords: multinationals, exporting, productivity JEL Classification: D24, F23

* For helpful comments and suggestions, I would like to thank my colleagues at the Bureau of Economic Analysis and participants at the Center for Economic Studies Seminar Series. Any opinions and conclusions expressed herein are those of the author(s) and do not necessarily represent the views of the U.S. Census Bureau or the U.S. Bureau of Economic Analysis. All results have been reviewed to ensure that no confidential information is disclosed. 


\section{Introduction}

Reductions in barriers to international trade and investment in recent decades have greatly expanded the opportunities for firms to become globally-engaged by beginning to export to, and/or do business in, a foreign country. These changes have also made it easier for multinational firms to increase the global scope of their operations by expanding the number of foreign countries in which they do business. The ability of firms to seize these foreign business opportunities rests on both the external environment and the firm's own capabilities. Theory suggests that a firm must possess certain proprietary assets that confer a productivity advantage over their nonmultinational rivals in order to become multinational. It has been shown that this advantage is positively correlated with the firm's global scope of operations. That is, those firms with the greatest productivity advantage are able to operate in the widest range of foreign countries. These findings suggest that not only are the most productive firms successful where it is relatively riskfree, easy, and economical to operate, but they are also able to overcome the additional costs and risks associated with operating in countries whose business climate is less favorable. This paper extends the existing research by measuring a multinational's productivity at the level of the individual establishment, rather than at the level of the consolidated business enterprise, and by demonstrating that the productivity advantage exists in both manufacturing and non-manufacturing industries. It also explores how outsourcing production to foreign affiliates affects domestic productivity.

Multinational firms are often at a disadvantage compared to their local competitors when operating in foreign countries because of additional costs that they must incur, such as adapting to unfamiliar laws and customs and finding qualified indigenous suppliers. Most of these risks and expenses can be considered "fixed costs" in the sense that they do not vary with a firm's 
scale of production. That is, they can generally be considered a one-time cost hurdle that multinationals must clear in order to operate profitably in foreign countries.

Hymer was the first to recognize that these costs play a fundamental role in understanding the location patterns of multinational firms (Hymer (1976)). ${ }^{1}$ He was dissatisfied with the classical economic theory of international investment, which did not distinguish between portfolio investment and direct investment, and which considered all international investment to be driven by price arbitrage, whereby capital flows from countries where it is abundant to where it is scarce (Mill (1891)). This explanation did not fit the patterns of U.S. foreign direct investment Hymer was witnessing in the mid-twentieth century. Capital was flowing overwhelmingly between countries with highly developed economies and not from those countries to lessdeveloped countries, as classical theory would predict. The missing element in the classical theory that Hymer identified is that direct investment capital flows are primarily driven by large firms that operate in imperfectly competitive markets. These large oligopolistic firms produce goods and services that are differentiated, in the eyes of buyers, from those produced by similar firms in other countries. These product differences may convey market power to the producers and allow them to earn profits sufficient to overcome the aforementioned fixed costs, those that Hymer called the "liability of foreignness." Hymer explained that firms are able to differentiate their products through proprietary knowledge, such as better product designs, advertising, or management, which he called "firm-specific assets."

Hymer's original insight laid a foundation for much of the subsequent empirical and theoretical research on the operations of multinational companies. The first group of studies uses reduced-form econometric models to

\footnotetext{
${ }^{1}$ Although Hymer's dissertation was finished in 1960, it was not published until 16 years later.
} 
identify a productivity advantage for multinational firms, which can be interpreted as resulting from the "firm-specific assets" of those firms. Researchers have successfully demonstrated this relationship using firm-level data for the United States (Doms and Jensen (1998)), Finland (Maliranta (1997)), the United Kingdom (Griffith (1999) and Criscuolo and Martin (2005)), Austria (Pfaffermayr and Bellak (2000)), and Belgium (de Backer and Sleuwaegen (2003)). All of them examined manufacturing industries only.

A second group of studies has fully articulated the linkage between multinationality and productivity using a structural model, and then tested it empirically. Markusen was the first to develop a structural model of foreign direct investment based on firm-specific assets (Markusen (1984)). Subsequent advances in structural modelling benefitted from studies of establishmentlevel productivity patterns, which were made possible by new data sets, such as the Longitudinal Business Database at the U.S. Bureau of the Census (Jarmin and Miranda (2002)). The firm-specific asset model suggests a significant and persistent disparity between business establishments that are owned by multinationals and those that are not. Consistent with these predictions, work by Bailey et al. (1992) found, on the one hand, a great deal of heterogeneity in the productivity of establishments within an industry and, on the other hand, a great deal of regularity in the relative productivity of individual establishments across time and across firms. Later studies added an international perspective to the productivity research by demonstrating that establishments that export their output are among the most productive (Bernard and Jensen (1999)).

The evidence of large and persistent differences in the productivity of U.S. business establishments and their connection to the global engagement of the parent firms led to further advances in structural modelling. Melitz developed a model of international trade in which firms in a given industry have random endowments of labor productivity (Melitz (2003)). The most productive 
firms become exporters either because they produce a higher quality product for which foreign buyers will pay a premium or because they produce a generic product at lower cost and offer their product to foreign buyers at a lower price. Either way, the most productive firms enjoy a profit advantage that allows them to overcome additional costs of exporting. This cost premium can entail per-unit costs (i.e. variable costs"), such as tariffs and transportation costs, as well as additional one-time costs (i.e "fixed costs"), such as market research and becoming familiar with the laws, customs, and business practices of foreign countries.

Helpman et al. extended Melitz's model by allowing firms to serve foreign markets both by exporting and by foreign direct investment (Helpman et al. (2004)). In their model, firms that engage in foreign direct investment must incur additional fixed costs beyond those required of exporters. ${ }^{2}$ They tested their model using industry-level data for U.S. exports and sales through U.S. direct investment abroad. Yeaple extended the Helpman et al. model by hypothesizing that the fixed costs of foreign direct investment will be higher for some markets than for others and that therefore the most productive firms will have the widest global scope of operations (Yeaple (2009)). He also supports his model using firm-level data for U.S. multinational firms. Altogether, the Helpman et al. and Yeaple studies find evidence of what Helpman et al. call a productivity "sorting pattern" in which firms must overcome successive cost hurdles as they expand the global scope of their operations (Figure 1).

\footnotetext{
${ }^{2}$ Zaheer organized these costs into four classes: (1) costs related to the physical distance between the home and host countries, such as travel and coordination costs, (2) firmspecific learning costs related to unfamiliarity with aspects of the local environment, such as laws or language, (3) country-specific risks related to host-country social norms and institutions, such as the risks of extortion and expropriation, and (4) costs related to restrictions imposed by the home country, such as the Foreign Corrupt Practices Act of the United States (Zaheer (1995)).
} 
There are several omissions and limitations in the empirical tests in the Helpman et al. and Yeaple studies that are addressed here. First, the precision of the productivity measures in those two studies could be increased. Helpman et al. employ a crude measure of labor productivity (sales-peremployee), which does not control for non-labor inputs to production. Yeaple employs a measure of total factor productivity, but he does not control for inputs other than labor and physical capital (such as purchases of raw materials). Helpman et al. measure productivity at the industry level. Yeaple measures productivity at the level of the consolidated business enterprise. This study, by contrast, measures productivity at the level of the individual business establishment. It also employs a comprehensive total factor productivity model that covers a variety of inputs to production, such as skilled and unskilled labor, physical capital, capitalized research and development, and purchased inputs. Both Helpman et al. and Yeaple examine only firms in manufacturing industries. This study examines firms in both goods-producing and services-producing industries. Finally, neither Helpman et al. nor Yeaple examine the effect of intrafirm trade, whereas this study examines the effect on the productivity of U.S. parent companies of imports of goods from foreign affiliates in both developed and less-developed countries. 


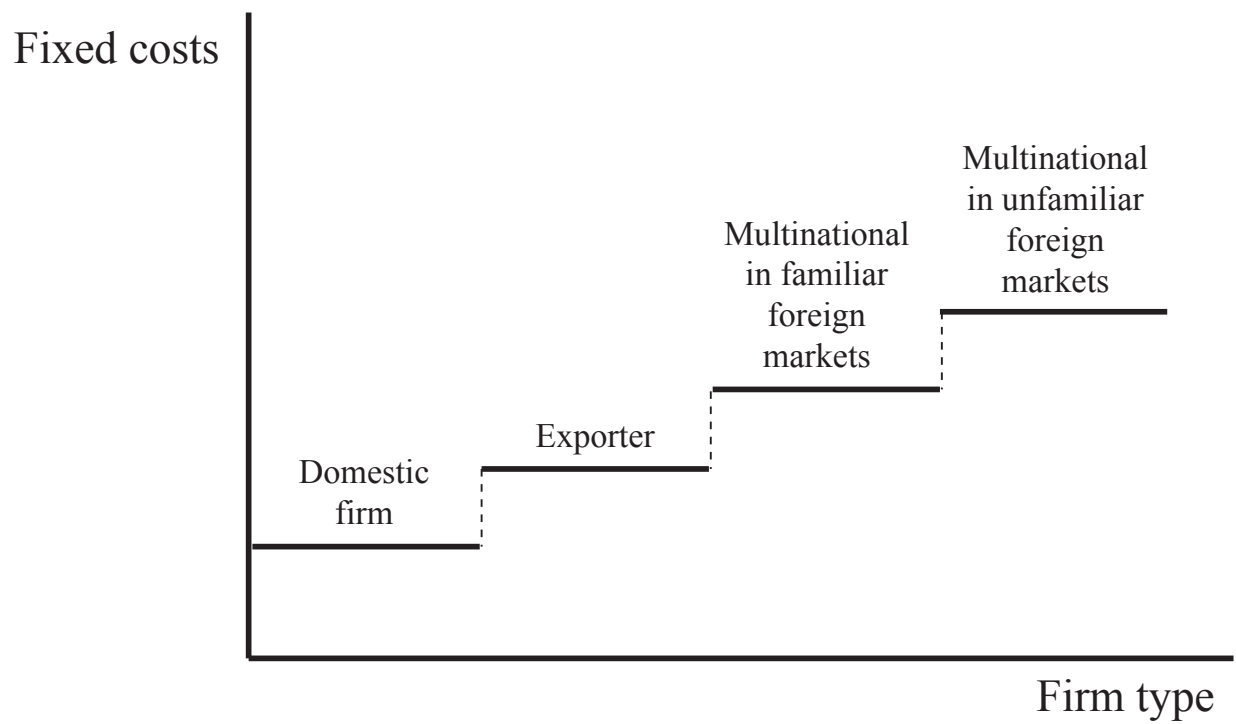

Figure 1: Productivity Sorting Model of Multinationals' Global Engagement

\section{Theoretical Predictions}

Global engagement.-The international business and economics literature has demonstrated that globally engaged firms tend to be endowed with proprietary assets, such as patents, management practices, or trademarks. Those assets, in turn, will tend to make a firm more productive, either through efficiency (producing more of a generic product at a lower cost) or through innovation (producing a new or differentiated product that customers value 
more highly than existing products). ${ }^{3}$ This productivity advantage allows globally engaged firms to earn profits sufficient to overcome the "liability of foreignness" and to serve foreign markets. Accordingly, establishments of globally engaged firms (exporters and multinationals) are expected to be more productive than those of non-globally engaged firms.

The liability of foreignness is greater when operating in a foreign country, than when serving a foreign market via exports because it requires the firm to interact much more extensively with the residents of that country. For example, in addition to learning about consumer tastes and product requirements in the foreign country, the firm must also develop the knowledge and connections necessary to do business in that country, such as finding local workers and suppliers. The costs and risks associated with these activities will tend to be greatest in foreign countries that are most dissimilar to the home country. As firms operate in less familiar locations, they must have an additional productivity advantage to overcome the additional costs and risks. Likewise, those firms that operate in less familiar environments decrease the risk of subsequent investments in such places through learning effects, and those that operate in a wide variety of environments may increase the ability to take on risk by spreading risk across a larger number of markets (Siddharthan and Lall (1982), p. 4). Accordingly, establishments of multinationals are expected to be more productive than establishments of enterprises that serve foreign markets only by exports. In addition, establishments of multinationals that operate in unfamiliar foreign markets are expected to be more productive than establishments of enterprises that operate only in familiar foreign markets.

The theoretical effect of being a U.S. affiliate of a foreign multinational is indeterminate. On the one hand, a U.S. affiliate could be expected to be

\footnotetext{
${ }^{3}$ Levinsohn and Melitz (Levinsohn and Melitz (2002), p.2) note that productivity, in a broad sense, can encompass "both productive efficiency and product quality."
} 
more productive than a U.S. parent of a U.S. multinational firm because it is operating outside of its home country and must overcome a greater liability of foreignness. On the other hand, multinationals tend to perform certain high-value-added activities mainly in the home country (such as strategic management and research and development), in part, to realize economies of scale and to facilitate the transmission of tacit knowledge inherent in some of these activities (Kogut and Zander (1993)).

Control variables.- In order to isolate the association between productivity and global engagement, it is necessary to introduce controls for other factors that can affect productivity.

Establishment size.-The effect of establishment size on productivity is theoretically indeterminate. On the one hand, larger establishments might confer productivity advantages through economies of scale in production. On the other hand, establishments might grow beyond their efficient scale and become overburdened with administrative costs and encumbered by bureaucratic routines. The empirical evidence is mixed. Some studies (e.g. Brush and Karnani (1996)) have found that the productivity enhancing effects of size dominate any negative effects. Others (e.g. Nguyen and Reznek (1990)) have found no significant relationship between establishment size and productivity. Because the theoretical effects offset one another, the productivity of U.S. business establishments is not expected to be related to establishment size.

Establishment age.-The effect of establishment age on productivity is theoretically indeterminate. On the one hand, older establishments have had the time to benefit from learning-by-doing. On the other hand, newer establishments are generally outfitted with the latest generation of capital goods which may be more productive than that of older cohorts. Empirical studies (e.g. Jensen et al. (2001)) have generally found that the positive 
and negative effects of establishment age tend to be offsetting. Because the theoretical effects offset one another, the productivity of U.S. business establishments is not expected to be related to establishment age.

Capital intensity.-Recent decades have seen an increase in the use of labor-saving and labor-augmenting technologies that have raised output per worker. Empirical studies (e.g. Dumas and Henneberger (1988)) have generally found a positive relationship between capital per worker and productivity. The productivity of U.S. business establishments is expected to be positively related to capital intensity of production.

Skill of the labor force.- The basic economic model of wage determination is based on the premise that workers are paid according to their marginal revenue product. Therefore more highly paid workers would be expected to produce a higher value of output. The productivity of U.S. business establishments is expected to be positively related to employee skill level.

The stock of RED assets is a proxy for the firm-specific assets that are expected to lend a productivity advantage to multinational firms. These assets can often be codified and easily transmitted across the various operating units of a multinational firm. The productivity of U.S. business establishments is expected to be positively related to the parent firm's stock of R\&D assets.

Industrial agglomeration.- There are a variety of productivity-enhancing effects of industrial agglomeration. There can be inter-industry effects such as the geographic concentration of firms in a particular industry attracting firms in supplying industries, which can reduce transportation costs and delays and facilitate communication between producers and their suppliers. There can also be intra-industry effects such as the geographic concentration of firms in a particular industry attracting a pool of workers with skills and experience 
relevant to the industry, or creating opportunities for firms to share ideas, such as through informal discussions in common social settings. A recent review of the literature (Glaeser and Gottlieb (2009)) suggests that agglomeration effects are significant and that the intra-industry effects are most important. The productivity of U.S. business establishments is expected to be positively related to the presence of industrial agglomeration.

Multiunit enterprises.- Businesses can either perform all of their functions in a single location, or they can allocate them to various units that can be both functionally and geographically separated. The former type of business is usually called a "single-unit firm" and the latter, a "multiunit firm." One benefit of being a single-unit firm is to realize production cost savings through economics of scale, whereas a benefit of being a multi-unit firm is to realize cost savings through economies of scope. The latter savings involve such benefits as heightened efficiencies from performing specialized tasks at large volumes, and from distributing certain fixed costs - such as accounting, marketing, and R\&D - over a greater number of business locations. (See Galliano and Soulie (2007) for a discussion of these effects.) Most empirical studies have found that belonging to a multiunit enterprise enhances a business enterprise's productivity (e.g. Jensen and McGuckin (1997)). The productivity of U.S. business establishments is expected to be positively related to belonging to a multiunit enterprise.

Outsourcing.-From the earliest articulations of international trade theory by David Ricardo (Ricardo (1817 (1996 reprint))), it has been demonstrated that economic efficiency can be attained through international specialization of production combined with trade. Multinational firms can internalize the resulting efficiency gains by geographically segmenting the stages of production in a way that exploits the comparative advantages of their home country and their foreign host countries (Helpman (1984)). Theory suggests 
that gains from international trade will be larger for countries with relative endowments of productive resources that are very different from those in the United States. The productivity of U.S. business establishments is expected to be positively related to outsourcing to foreign affiliates and is greater for trade with affiliates in countries with less-developed economies than for trade with affiliates whose economies resemble that of the United States.

\section{Data \& Methods}

The data used in this study disaggregates the BEA data on the domestic and foreign operations of U.S. multinational firms in new ways that were not possible for Helpman et al. (2004) and Yeaple (2009). It is now possible to see whether the productivity patterns illustrated by those authors using data for industries and individual business enterprises is present at the much more disaggregated level of the individual business establishment. Establishment-level data overcome the possibility of aggregation bias that occurs when patterns in the aggregate data are not prevalent in the underlying disaggregated data. The new data also make it possible to see whether the productivity sorting patterns that those authors demonstrated for manufacturing industries exist in non-manufacturing industries as well.

The data used in this study combines BEA data on the domestic and foreign operations of U.S. multinational firms with data from the 2002 economic census on the domestic operations of all U.S. business establishments. ${ }^{4}$ This data set affords the opportunity to compute the first ever estimates of establishment-level productivity by U.S. multinationals in the United States, based on the BEA data. It also allows us to explore the sources of that productivity using data on the domestic and foreign operations of U.S. multina-

\footnotetext{
${ }^{4}$ Excludes finance and wholesale and retail trade because a reliable measure of productivity is not available for business establishments in these industries.
} 
tional firms and on the operations of non-multinational U.S. businesses.

This paper investigates the relationship between a multinational's global engagement and its productivity, while controlling for a variety of factors associated with high productivity U.S. business establishments. It attempts to isolate the size of the productivity advantage associated with each degree of global engagement, varying from having no exports or foreign affiliates, to exporting, to having a highly developed network of foreign affiliates.

The productivity of U.S. business establishments in a single year (2002) is regressed on several variables indicating the extent of the parent enterprise's global engagement. The measures of global engagement are: a dummy variable indicating whether the establishment is not part of a multinational firm and exports some of its output, a dummy variable indicating whether the establishment is part of a multinational firm (either a U.S. parent of a U.S.based multinational firm or a U.S. affiliate of a foreign-based multinational firm), a dummy variable indicating whether the establishment is owned by a foreign-based multinational firm, and a measure of the global scope of the operations of the U.S. parent enterprise. The global scope variable takes into account the number of foreign host countries in which a U.S. multinational operates, the relative size of those operations, and the level of economic development of the host counties, and serves as a crude proxy for the additional costs and risks that the parent experiences as the scope of its operations outside of the United States increases. A firm encounters new costs and risks when entering a geographic region for the first time, as it must become familiar with the prevailing customs, languages, and institutions. In addition, as firms expand globally, they find that their transportation and coordination costs increase. Thus, the measure of global scope used here is based on the following formula:

$$
\left\{\sum_{i=1}^{n}\left(Y_{u s}-Y_{c}\right)\left(\frac{e m p_{c}}{e m p_{w w}}\right)\right\} * r
$$


where the parent enterprise operates in foreign countries $c=1, \ldots, n, Y_{u s}$ is per-capita income in the United States, $Y_{c}$ is a PPP-based estimate of percapita income in the host country, $e m p_{c}$ is the total employment of foreign affiliates of the parent enterprise in country $c, e m p_{w w}$ is worldwide employment of foreign affiliates of the parent enterprise, and $r$ is the number of geographic regions in which the parent enterprise has foreign affiliates. ${ }^{5}$ The data on the operations of foreign affiliates are from the BEA, and the data on per-capita host-country income are from the World Bank.

To illustrate the measure of global scope, consider the case of two hypothetical multinational companies. Company A has ten thousand employees worldwide with 1,000 in Canada and the rest in the United States. Company $\mathrm{B}$ has ten thousand employees worldwide with 1,000 in Canada, 1,000 in Thailand, and the rest in the United States. The measure of global scope for Company A would be the difference between the per-capita incomes of the United States and Canada (roughly \$8,000 in 2002) times the fraction of the worldwide employment of Company A in Canada (10 percent), or $\$ 800$. The measure of global scope for Company B is calculated in three stages. First, the portion of global scope index for the investment in Canada is calculated in the same way as for Company A, yielding $\$ 800$. Second, the portion of the index for the investment in Thailand is calculated as the difference between the per-capita incomes of the United States and Thailand (roughly $\$ 32,000$ in 2002) times the fraction of the worldwide employment of Company B in Thailand (10 percent), or $\$ 3,200$. Finally, the two parts are added together and then multiplied by two (for the number of global regions in which Company B operates), yielding a global scope index of $\$ 8,000$ $((\$ 800+\$ 3,200) \times 2))$.

Dependent variable.-The choice of an appropriate measure of produc-

\footnotetext{
${ }^{5}$ The six geographic regions used are North America, Central and South America, Europe, Middle East, Africa, and Asia.
} 
tivity for microdata research has been carefully examined. This literature is reviewed by Bartelsman and Doms (2000). They point out that total factor productivity is conceptually superior to labor productivity because it captures the input of all factors of production, but also note that empirically "heterogeneity in labor productivity has been found to be accompanied by similar heterogeneity in total factor productivity"(p. 575). This study employs both measures and also finds that, as in other empirical work, results using the two measures are not materially different. For manufacturing industries, two regressions were estimated: one using a measure of labor productivity, specifically value added per employee, and one using the residual from a Cobb-Douglas production function as a measure of total factor productivity. For nonmanufacturing industries, the dependent variable in the regression is a measure of labor productivity, specifically, sales (or revenue) per employee.

Control variables.-For manufacturing establishments, the control variables for the labor productivity regression include establishment size, the parent firm's stock of R\&D assets, industrial agglomeration, establishment age, and whether the establishment is part of a multiunit enterprise, the capital intensity of production, average skill of the labor force, and outsourcing to affiliates in less-developed countries (LDCs) and in member countries of the Organisation for Economic Co-Operation and Development (OECD). Outsourcing effects are separately measured for these two geographic regions because of expected differences in the motivations in the investments. Imports from affiliates in LDCs are expected to be primarily motivated by labor cost savings, whereas imports from affiliates in OECD countries are expected to be primarily motivated by intangible inputs to production (such as superior product design or brand image). A variable for the establishment's 4-digit industry is included to control for differences in the typical production tech- 
nologies used in different industries. ${ }^{6}$ The total factor productivity regression is estimated in two stages. In the first stage, total output is regressed on the establishment's identifiable factors of production: production workers, nonproduction workers, the parent firm's stock of R\&D assets, gross book value of fixed assets, and purchased materials. The residuals from that regression are assumed to represent the contribution to productivity of factors other than labor and capital, including the elements of primary interest here, i.e. those related to the global engagement of the parent firm. In the second stage, the regression residuals are regressed on industrial agglomeration, establishment age, whether the establishment is part of a multiunit enterprise, and outsourcing to LDC and OECD countries. The econometric technique used is ordinary least squares. Because the results could be strongly influenced by outliers, very small establishments (those with fewer than 5 employees) are excluded from the analysis. In the variable descriptions that follow, the data are from the United States 2002 Census of Manufactures, Census of Construction, Census of Mining, Census of Transportation, Communications and Utilities, and Census of Service Industries, except where noted.

The control variables for non-manufacturing establishments, in general, and services establishments, in particular, include establishment size, the parent firm's stock of R\&D assets, industrial agglomeration, establishment age and 4-digit industry, and whether the establishment is part of a multiunit enterprise.

Brief descriptions of the specification of the control variables follow.

Establishment size is the number of employees at the establishment.

Establishment age is the number of years between when the establishment is first observed in the Census Bureau Longitudinal Business Database and

\footnotetext{
${ }^{6}$ Although the source data contained industry detail at the 6-digit level, a 4-digit level of precision was chosen to ensure sufficient sample sizes.
} 
the year 2002. All business establishments that came into existence in, or before, 1975 have the maximum age of 27 years, because that is the earliest year that is covered by the Longitudinal Business Database.

Capital intensity of production is the gross book value of depreciable assets per employee, expressed in thousands of U.S. dollars. Researchers have generally found that simple measures of capital stock, such as this one, perform as well as more sophisticated measures of capital stock when estimating production functions using microdata (e.g. Dwyer (1997)).

Skill of the labor force is the share of nonproduction workers in the labor force.

The stock of RED assets is the accumulated stock of intellectual assets generated by the parent enterprise through research and development. It is based on the five year (1998-2002) accumulation of R\&D expenses reported on the Census Bureau's Survey of Industrial Research and Development, excluding depreciation. Different accumulation periods (e.g. 1-year or 10-year) yielded essentially the same results as the 5-year accumulation period chosen. This variable is expressed in millions of U.S. dollars.

Industrial agglomeration is measured using a location quotient (Barber (1988), pp. 87-88)). The location quotient measures the industrial specialization of a geographic region by comparing the weight of a specific industry in a region to the weight of that industry in a larger geographic area. It is calculated using data from the United States 2002 economic censuses based on the following formula:

$$
\frac{s^{i} c}{s^{i} u s}
$$

where $s^{i}{ }_{c}$ is industry $i$ 's share of total employment in county $c$ and $s^{i}$ us 
is industry $i$ 's share of total employment in the entire United States. The presence of industrial agglomeration is indicated by an index significantly greater than one.

Multiunit enterprises are indicated with a binary dummy variable that takes the value of one when the business establishment is part of a multiunit enterprise and takes a value of zero when the business establishment is a single unit.

Outsourcing.- The extent to which the parent enterprise outsources production to its foreign affiliates is captured by the dollar value of imports of goods from foreign affiliates. Imports from member countries of the OECD, excluding Mexico (Outsourcing OECD) and imports from non-member countries and Mexico (Outsourcing LDC) are treated as separate variables because there can be different motivations for outsourcing to these different types of countries. This variable is expressed in millions of U.S. dollars.

\section{Results}

The results of the statistical analysis strongly support the basic proposition that higher productivity is associated with firms with greater global engagement, although there are a few unexpected results, particularly for some of the control variables. The results, based on four specifications, are presented in table 1 . The first three columns of the table present the results using labor productivity as a dependent variable: sales per employee for all non-manufacturing industries (column 1) and for service industries in particular (column 2), and value added per employee for manufacturing (column 3). The results in column 4, which cover manufacturing only, use total factor productivity as the dependent variable. In the regressions, only the dependent variable is expressed as a natural log so the coefficients can 
be interpreted as the percentage change in the dependent variable associated with a one-unit change in the independent variable.

The estimated coefficients are strongly robust to the different data samples and the different productivity measures. Those on the variables of main interest strongly support the hypothesis of a productivity advantage for globally engaged firms. Depending on the specification and data sample used, establishments of non-multinationals that exported were between 9.2 percent and 34.7 percent more productive than establishments that did not. This result is especially pronounced for service industries. It may be that, within a given industry, the services produced by service exporters require a much higher skill level than services produced by non-exporters, and that this difference is more pronounced than in manufacturing industries. The establishments of multinational firms (either U.S.-based multinationals or foreignowned firms in the United States) were between 2.1 percent and 23.6 percent more productive than establishments of firms that were not. Evidence for the hypothesis that multinationals are more productive than firms export only is mixed: The productivity advantage of manufacturing establishments that belonged to U.S. multinational firms is greater than the productivity advantage of manufacturing establishments that exported but were not part of a multinational. For service industries, this situation is reversed. The positive and significant coefficients on the geographic scope variable confirm the hypothesis that establishments of multinationals that operate in unfamiliar foreign markets are more productive than establishments of enterprises that operate only in familiar foreign markets.

Turning to the control variables, the coefficients on establishment size for establishments of services firms suggest that a one-thousand-employee increase in the size of establishment would be associated with a 6-percent decrease in the productivity of the establishment, implying that larger establishments in these industries have grown beyond their maximum efficient 
Table 1: Regression Results

\begin{tabular}{|c|c|c|c|c|}
\hline & \multicolumn{3}{|c|}{ Labor productivity } & TFP \\
\hline & \multirow{2}{*}{$\begin{array}{c}\text { Non-manufac- } \\
\text { turing }\end{array}$} & \multirow{2}{*}{$\begin{array}{c}\text { Services } \\
(2)\end{array}$} & \multicolumn{2}{|c|}{ Manufacturing } \\
\hline & & & (3) & (4) \\
\hline Capital intensity & n.a. & n.a. & $0.00115^{* *}$ & f.s. \\
\hline Skill of the labor force & n.a. & n.a. & $0.00335 * *$ & f.s. \\
\hline Establishment size & $-0.00006^{* *}$ & $-0.00007^{* *}$ & 0.00000 & f.s. \\
\hline Stock of R\&D assets & $0.00003^{* *}$ & $0.00003^{* *}$ & $0.00001^{* *}$ & f.s. \\
\hline Industrial agglomeration & $0.00101^{* *}$ & $0.04530^{* *}$ & $-0.00050^{*}$ & $-0.00105^{* *}$ \\
\hline Establishment age & $0.00157^{* *}$ & $0.00158^{* *}$ & -0.00006 & -0.00026 \\
\hline Multiunit enterprise & $0.26334^{* *}$ & $0.25237^{* *}$ & $0.16506^{* *}$ & $0.17817^{* *}$ \\
\hline Outsourcing to LDCs & n.a. & n.a. & $-0.00012^{* *}$ & $-0.00012^{* *}$ \\
\hline Outsourcing to OECD countries & n.a. & n.a. & $0.00005^{* *}$ & 0.00000 \\
\hline Exporter & n.a. & $0.34674^{* *}$ & $0.10014^{* *}$ & $0.09226^{* *}$ \\
\hline Multinational & $0.05990^{* *}$ & $0.03436^{* *}$ & $0.16520^{* *}$ & $0.16113^{* *}$ \\
\hline Foreign owned & $0.18593^{* *}$ & $0.23564^{* *}$ & 0.02122 & $0.03064^{* *}$ \\
\hline Geographic scope & $0.00099^{* *}$ & $0.00247^{* *}$ & $0.00236^{* *}$ & $0.00060^{* *}$ \\
\hline$n$ & $\sim 375,000$ & $\sim 333,000$ & $\sim 178,000$ & $\sim 178,000$ \\
\hline R-squared & 0.3852 & 0.2991 & 0.2743 & 0.0495 \\
\hline
\end{tabular}

** 1-percent significance level

* 5-percent significance level

All regressions include 4-digit NAICS industry dummies.

f.s. A related variable was included in the first stage of the two stage regression.

LDC Less developed country

n.a. The necessary data were not available.

OECD Organisation for Economic Co-Operation and Development

TFP Total factor productivity 
scale. The insignificance of the coefficient on this variable in manufacturing is consistent with the opposing theoretical effects of establishment size.

The coefficients on the variable for establishment age is positive and significant in non-manufacturing industries, but is small in magnitude. A oneyear increase in the age of an establishment would be associated with a 0.2 percent increase in the productivity of establishments in non-manufacturing industries in general and of establishments in service industries in particular. This weak impact, and the insignificance of this variable for establishments in manufacturing, are consistent with the opposing theoretical effects of establishment age.

The positive coefficients on capital intensity of production and skill of the labor force for manufacturing establishments are as predicted. A $\$ 1$ thousand increase in the gross book value of depreciable assets per employee of an establishment would be associated with a 0.1 percent increase in productivity. A ten-percentage-point increase in the share of nonproduction workers in the total labor force of an establishment would be associated with a 3.4 percent increase in productivity.

The positive and significant coefficient on the stock of $R \& D$ assets is consistent with the theoretical expectation. A $\$ 100$ million increase in the stock of these assets would be associated with a 0.3 -percent increase in productivity in non-manufacturing industries and a 0.1-percent increase in manufacturing industries.

The coefficients on industrial agglomeration fit the theoretical prediction for nonmanufacturing and service industries, but not for manufacturing industries. In neither case is the effect very strong. In service industries, a ten percent increase in the location quotient would be associated with only a 0.5 percent increase in productivity; in nonmanufacturing industries in general, the effect would be much smaller-only 0.01 percent. In manufacturing industries, a ten percent increase in the location quotient would be associated 
with a negative 0.01 percent decrease in productivity.

The large and positive coefficients on the multiunit enterprise dummy variable are consistent with the theoretical expectation and suggest that this characteristic accounts for a large portion of the productivity advantage of business establishments in this class. Compared to single-unit establishments, these establishments were 26.3 percent, and 25.2 percent, more productive, respectively, in nonmanufacturing industries in general and in services in particular.

The coefficients on outsourcing to foreign affiliates are largely at odds with the theoretical expectation. The expected positive effect on productivity is only found for trade with member countries of the OECD (excluding Mexico) whose factor endowments tend to be similar to those in the United States. In the labor productivity regression, a $\$ 100$ million increase in imports of goods from affiliates in these countries would be associated with a 0.5 -percent increase in productivity. The opposite effect is found for trade with affiliates in other countries (a proxy for less-developed countries). A \$100 million increase in imports of goods from affiliates in less developed countries would be associated with a 1.2-percent decrease in productivity. This result is at odds with the theoretical expectation and may be related to the inability to completely control for the type of product being manufactured. Although this study uses detailed industry controls (4-digit NAICS industries), there can even be wide differences in the market power (and, hence, performance) of producers in these industries. In NAICS industry 3111 (animal food manufacturing), for example, the products can range from commodities, such as feed corn, to prescription pet foods. Casual inspection of the data in this industry suggests that firms in the former category are more likely to source from affiliates in low-wage countries than the latter category, which is consistent with customers being more price-conscious in the low-end product 
categories. ${ }^{7}$ If this casual observation holds in general, it suggests that empirical studies wishing to uncover the productivity-enhancing effects of vertical specialization in multinational firms need to take great care in assuring that industry controls are done at a very detailed product level. Although, as noted earlier, sample sizes may be insufficient if industry or product detail is too specific.

\section{Conclusion}

This study has extended the recent literature on the productivity sorting model of multinational firms. These extensions have been made possible by combining BEA enterprise-level data on the U.S. operations of U.S. multinational firms with data on all U.S. business establishments collected by the Census Bureau in the U.S. economic census covering 2002. The first extension of the literature is to measure productivity at the level of the individual business establishment rather than the consolidated business enterprise. This extension greatly increases the utility of industry controls in the regression analysis. The second extension is to see if the theory holds in nonmanufacturing industries as well as in manufacturing industries. The third extension is to examine the effect on the productivity of U.S. parent companies of imports of goods from foreign affiliates in both developed and less-developed countries.

The results for manufacturing business establishments are fully consistent with Helpman, Melitz, and Yeaple's productivity sorting models of multinational firms. Establishments that export at least a portion of their output

\footnotetext{
${ }^{7}$ Such a result would be consistent with the studies demonstrating that multinationals in labor-intensive industries, which generally produce low value goods, are more likely to establish foreign affiliates in less developed countries than multinationals in capitalintensive industries. See, for example, Borga and Lipsey (2004).
} 
are more productive than establishments that do not serve foreign markets at all. Establishments that are members of a multinational business enterprise are more productive still, and establishments of multinational business enterprises with the widest global scope of operations are most productive of all. The results for services industries confirm the basic productivity advantage associated with serving foreign markets but, curiously, establishments of firms that serve foreign markets only through exports are more productive than establishments of multinational business enterprises. Perhaps the production functions of service firms that serve foreign markets only through exports intensively use highly skill technical workers who are relatively abundant in the United States.

The unexpectedly negative effect of imports from affiliates in less developed countries is at odds with the theoretical prediction, which suggests a problem with the research design. The most likely problem seems to be that the NAICS industry controls are not fine enough to control for differences in the nature of the products being produced and sold. A future extension to this paper would be to attempt to exploit the much more detailed product codes that are also available in the Census Bureau data sets. 


\section{References}

Bailey, Martin Neil, Charles Hulten, David Campbell, Timothy Bresnahan, and Richard E. Caves (1992). "Productivity dynamics in manufacturing plants." Brookings Papers on Economic Activity, Microeconomics 1992, $187-267$.

Barber, Gerald M. (1988). Elementary Statistics for Geographers. New York: The Guilford Press.

Bartelsman, Eric J. and Mark Doms (2000). "Understanding productivity: Lessons from longitudinal microdata." Journal of Economic Literature 38(3), 569-594.

Bernard, Andrew B. and J. Bradford Jensen (1999). "Exceptional exporter performance: Cause, effect, or both?" Journal of International Economics 47(1), 1-25.

Borga, Maria and Robert E. Lipsey (2004). "Factor prices and factor substitution in U.S. firms' manufacturing affiliates abroad." Working Paper 10442, National Bureau of Economic Research.

Brush, Thomas and Aneel Karnani (1996). "Impact of plant size and focus on productivity: An empirical study." Management Science 42(7), 10651081.

Criscuolo, Chiara and Ralf Martin (2005). "Multinationals, foreign ownership and U.S. productivity leadership: Evidence from the U.K." Discussion Paper dp0672, Centre for Economic Performance.

de Backer, Koen and Leo Sleuwaegen (2003). "Foreign ownership and productivity dynamics." Economics Letters 79, 177-183. 
Doms, Mark E. and J. Bradford Jensen (1998). "Comparing wages, skills, and productivity between domestically and foreign- owned manufacturing establishments in the United States." In Robert E. Baldwin, Robert E. Lipsey, and J. David Richardson, eds., Geography and Ownership as Bases for Economic Accounting, pp. 235-255. Chicago: University of Chicago Press.

Dumas, Mark W. and J. Edwin Henneberger (1988). "Productivity trends in the cotton and synthetic broad woven fabrics industry." Monthly Labor Review 111(4), 34-38.

Dwyer, Douglas W. (1997). "Productivity races II: The issue of capital measurement." Working Paper 97-3, Center for Economic Studies.

Galliano, Danielle and Nicolas Soulie (2007). "Organisational and spatial determinants of the multiunit firm: Evidence from the French industry." Cahier 17, Groupement de Recherches Economiques et Sociales.

Glaeser, Edward L. and Joshua D. Gottlieb (2009). "The wealth of cities: Agglomeration economies and spatial equilibrium in the United States." Working Paper 14806, National Bureau of Economic Research.

Griffith, Rachel (1999). "Using the ARD establishment level data to look at foreign ownership and productivity in the United Kingdom." The Economic Journal 109(456), F416-F442.

Helpman, Elhanan (1984). "A simple theory of trade with multinational corporations." Journal of Political Economy 92(3), 451-471.

Helpman, Elhanan, Marc J. Melitz, and Stephen R. Yeaple (2004). "Export versus FDI with heterogeneous firms." American Economic Review 94(1), 300-316. 
Hymer, Stephen H. (1976). The International Operations of National Firms: A Study of Direct Foreign Investment. Cambridge, MA: The MIT Press.

Jarmin, Ron S. and Javier Miranda (2002). "The longitudinal business database." Working Paper CES-WP-02-17, U.S. Department of Commerce, Bureau of the Census.

Jensen, J. Bradford and Robert H. McGuckin (1997). "Firm performance and evolution: Empirical regularities in the U.S. microdata." Industrial and Corporate Change 6(1), 25-47.

Jensen, J. Bradford, Robert H. McGuckin, and Kevin Stiroh (2001). "The impact of vintage and survival on productivity: Evidence from cohorts of U.S. manufacturing plants." The Review of Economics and Statistics 83(2), 323-332.

Kogut, Bruce and Udo Zander (1993). "Knowledge of the firm and the evolutionary theory of the multinational corporation." Journal of International Business Studies 24, 625-645.

Levinsohn, Jerome and Marc Melitz (2002). "Productivity in differentiated products market equilibrium." Working paper, University of Michigan.

Maliranta, Mika (1997). "Plant productivity in finnish manufacturing." Discussion Paper 612, ETLA.

Markusen, James R. (1984). "Multinationals, multi-plant economies, and gains from trade." Journal of International Economics 16(3-4), 205-226.

Melitz, Marc J. (2003). "The impact of trade on intra-industry reallocations and aggregate industry productivity." Econometrica 71(6), 1695-1725.

Mill, John S. (1891). Principles of Political Economy. New York: Appleton \& Co. 
Nguyen, Sang V. and Arnold P. Reznek (1990). "Returns to scale in small and large U.S. manufacturing establishments." Working Paper 90-11, Center for Economic Studies.

Pfaffermayr, Michael and Christian Bellak (2000). "Why foreign-owned firms are different: A conceptual framework and empirical evidence for austria." Working Paper 115, Hamburg Institute of International Economics.

Ricardo, David (1817 (1996 reprint)). Principles of Political Economy and Taxation. Amherst, NY: Prometheus Books.

Siddharthan, N.S. and Sanjaya Lall (1982). "The recent growth of the largest U.S. multinationals." Oxford Bulletin of Economics and Statistics 44(1), $1-13$.

Yeaple, Stephen Ross (2009). "Firm heterogeneity and the structure of U.S. multinational activity." Journal of International Economics 78, 206-215.

Zaheer, Srilata (1995). "Overcoming the liability of foreignness." The Academy of Management Journal 38(2), 341-363. 